\title{
KEEFEKTIVITASAN PENGGUNAAN MEDIA MOBILE \\ LEARNING DALAM MENINGKATKAN PELAFALAN \\ HANYU PINYIN BAHASA MANDARIN
}

\author{
Budi Hermawan, Ong Peter Leonardo \\ Universitas Widya Kartika Surabaya, budi_bh1 @yahoo.co.id \\ Universitas Widya Kartika Surabaya, 1185641324@qq.com
}

\begin{abstract}
Globalisation Era will be faced Indonesia in 21st century. Chinese Language's role is really needed in many aspect and sectors. Human resources who expert in foreign language are really needed as a bridge to cooperate between Indonesian and other countries. At this time the quantity student of Chinese Language in Indonesia have increased very fast. Many students with many ways have joined to expert Chinese Language in formal education or nonformal education. They all of them have tried to expert this foreign language. But there is a problem for Indonesian students to learn Chinese Language. The problem is a quite diffrent pronounciation with Indonesia Language before. So, at the last time so many students have given up to decide dismiss from the particular Chinese lesson. At this century, the technology also increase very fast. It's related with many application to the smart phone. In the beginning of 2000th year, it has increased android system and ios which so many person have these system with many diffrent type. From the qualitative research method that we had done before. It's known that the student of Chinese Language in using mobile learning can support to learn pronounciation, expecially for the consonant.
\end{abstract}

Keywords: Mandarin Languages, Hanyu Pinyin, Mobile Learning 
Budi Hermawan dan Ong Peter L, Keefektifan Penggunaan... (hlm. 308-322)

\section{PENDAHULUAN}

Pada era globalisasi ini, masyarakat Indonesia mulai menyadari akan pentingnya Ilmu Bahasa. Ilmu Bahasa merupakan keterampilan khusus yang dibutuhkan dalam berkomunikasi. Mempelajari Ilmu Bahasa merupakan investasi yang baik untuk diri sendiri, karena Semakin mahir Bahasa asing yang kita kuasai maka semakin banyak pula peluang dan kesempatan positif yang akan kita dapat dalam kehidupan sehari-hari, bisnis dan pendidikan. Kini telah banyak sekolahsekolah di Indonesia yang menawarkan banyak Ilmu Bahasa dalam kegiatan pembelajarannya, baik sebagai mata pelajaran wajib maupun sebagai muatan lokal atau ekstrakulikuler. Diantara sekian banyak ilmu Bahasa Asing yang ditawarkan, Bahasa Mandarin merupakan salah satu bahasa yang paling diminati dan dibutuhkan dalam dunia komunikasi atau bisnis. Karena pentingnya Bahasa Mandarin saat ini, maka proses pembelajaran Bahasa Mandarin sebagai Bahasa Asing perlu perhatian khusus. Sebagai dasarnya, pelajaran Bahasa Mandarin kini sudah diajarkan dari TK, Sekolah Dasar sampai dengan Perguruan Tinggi.

Bagi Pembelajar Indonesia Bahasa Mandarin merupakan Bahasa Asing yang di dalam pelafalannya orang Indonesia sangatlah tidak familiar. Dikarenakan di dalam bahasa Mandarin memiliki cirri khas dan kekhususan dalam melafalkan vokal dan konsonannya serta nada yang tidak dimiliki di dalam Bahasa Indoneisa. Dalam mempelajari Bahasa Mandarin, ada beberapa pokok yang merupakan dasar dalam mempelajari Bahasa Mandarin yaitu : Pelafalan Hanyu Pinyin yang terdiri dari shengmu, уипти dan shengdiao, selain daripada itu Karakter Mandarin (hanzi) juga merupakan bagian yang tidak terpisahkan dalam pembelajaran bahasa Mandarin. Beberapa pokok diatas itulah yang membuat orang memiliki ketertarikkan dan merasa memiliki tantangan dalam mempelajari Bahasa Mandarin. Bagi sebagian besar orang, salah satu yang membuat Bahasa Mandarin sulit dipelajari adalah Pelafalan Bahasa Mandarin yang berbeda dengan Pelafalan 
bahasa Indonesia dan hal tersebut bisa menimbulkan salah satu hambatan dalam berkomunikasi.

Berdasarkan Latar Belakang tersebut Peneliti akan melakukan analisa kesalahan pelafalan pembelajar Bahasa Mandarin. Dengan melakukan analisa kesalahan Pelafalan Hanyu Pinyin, Pengajar Bahasa Mandarin akan memahami kesalahan-kesalahan pelafalan yang sering ditemui pembelajaran Indonesia dan Pengajar dapat menggunakan media yang tepat dan menarik untuk dapat meningkatkan kompetensi pelafalan Bahasa Mandarin pembelajar.

Sejalan dengan perkembangan teknologi yang terjadi hingga dekade ini, perkembangan Handphone terjadi dengan sangat pesat. Selain digunakan untuk berkomunikasi bertelepon dan berkirim pesan SMS, peran Handphone telah bergeser menjadi alat media sosial dan alat bermain games. Berbagai Aplikasi pun dapat dengan mudah di unduh di dalam sistem Android ataupun IOS. Seiring perkembangan teknologi, aplikasi pembelajaran bahasa Mandarin pun dapat dengan mudah diunduh untuk dipasang di dalam sistem ponsel.

Untuk menghadapi masalah yang dialami pembelajaran Bahasa Mandarin pemula dalam mempelajari Pelafalan konsonan Hanyu Pinyin, sehingga dalam proses pembelajaran diperlukan media pembelajaran tambahan yang memudahkan pembelajar pemula untuk meningkatkan penguasaan kemampuan Berbahasa Mandarin. Penelitian tentang keefektivitasan media pembelajaran mobile learning diperlukan agar mengetahui dan memastikan apakah peran Aplikasi Pembelajaran di Ponsel bisa dimanfaatkan untuk meningkatkan Kemampuan pelafalan konsonan Hanyu Pinyin Bahasa Mandarin.

\section{PEMBAHASAN}

\section{Metode Penelitian}

Secara umum permodelan pembelajaran dari penelitian berjudul Keefektivitasan Penggunaan Media Mobile Learning Dalam Meningkatkan 
Budi Hermawan dan Ong Peter L, Keefektifan Penggunaan... (hlm. 308-322)

Pelafalan "Hanyu Pinyin" Bahasa Mandarin ini dapat diajabarkan dalam skema penelitian sebagai berikut:

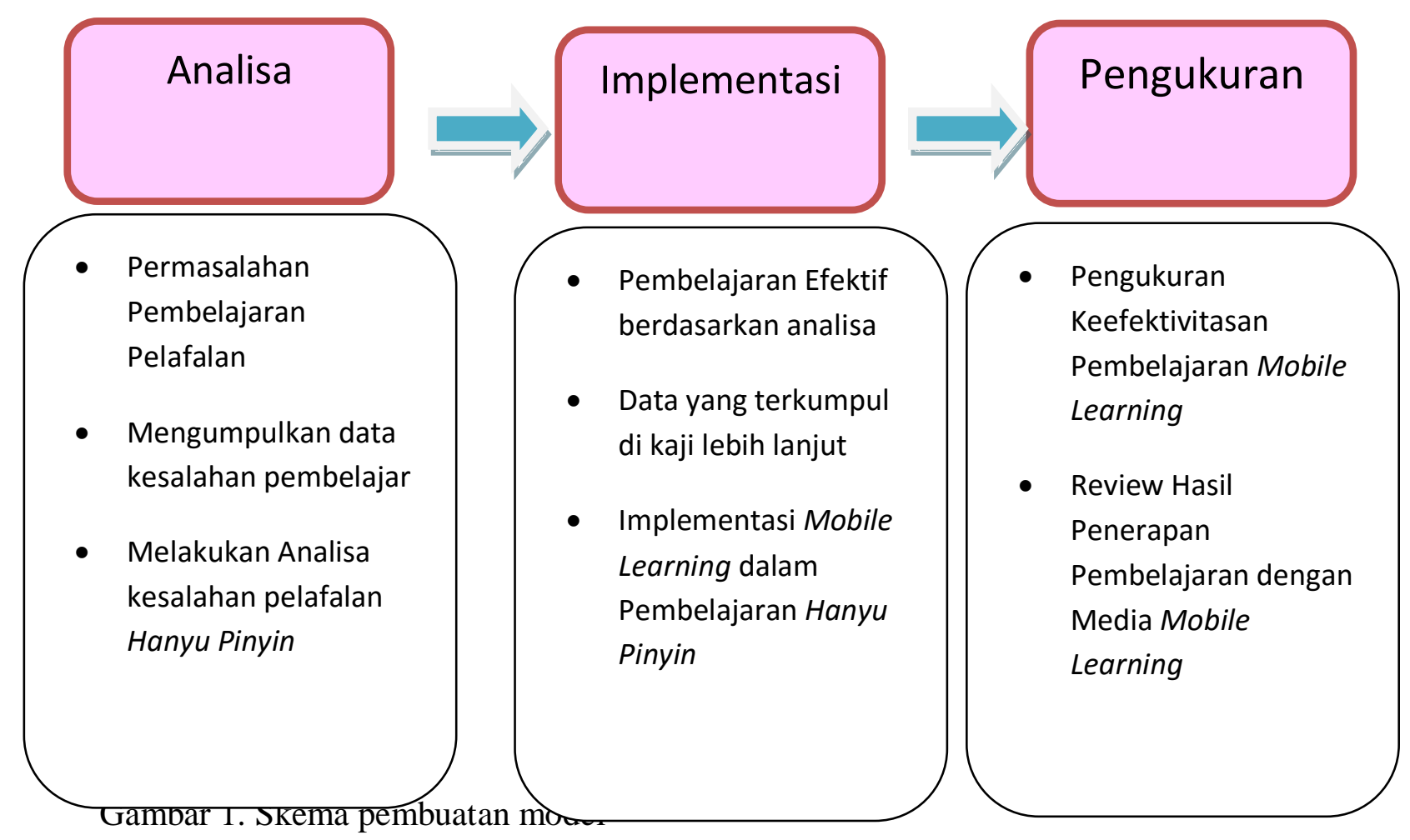

Berdasarkan gambar 1. Dapat dijelaskan sebagai berikut, peneliti melakukan pengumpulan data kesalahan pelafalan yang dilakukan oleh pembelajar Indonesia dalam mempelajari pelafalan bahasa Mandarin. Model yang digunakan untuk menggali permasalahan-permasalahan tersebut adalah menggunakan metode penelitian kualitatif dan kuantitatif.

Penelitian kualitatif dilaksanakan dengan tujuan untuk menganalisa kesalahan pelafalan Hanyu Pinyin, sedang penelitian kuantitatif dilaksanakan untuk mengkaji data yang terkumpul dan mengukur keefektivitasan Pembelajaran Mobile Learning.

Secara umum metode kualitatif dan kuantitatif dapat digambarkan dalam diagram di bawah ini: 


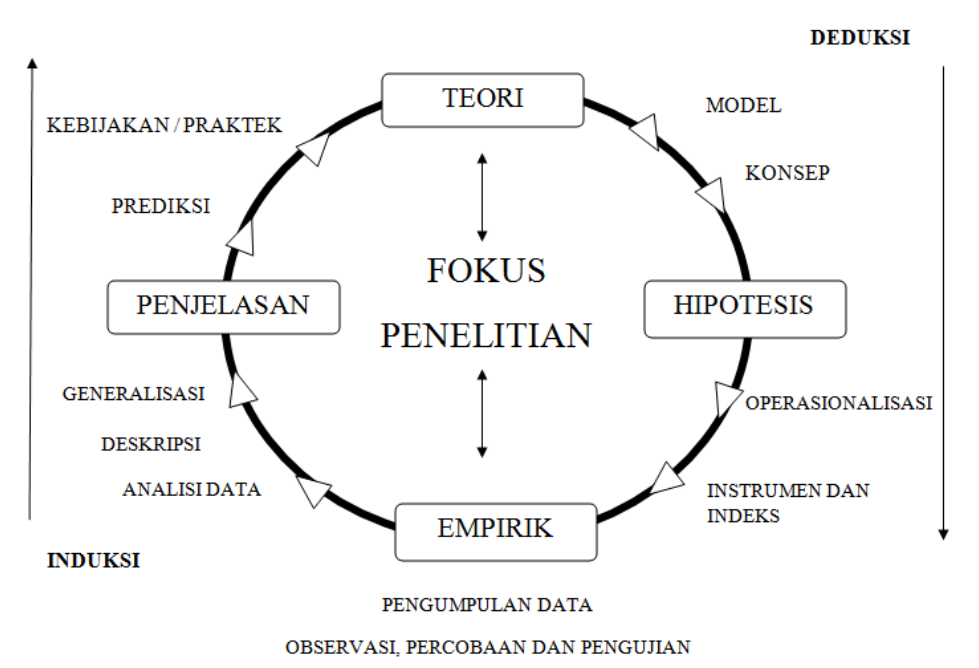

Diadaptasi dari Marshall dan Rossman 1983:23

Dalam melakukan penelitian ini, akan dilakukan observasi terlebih dahulu terhadap pembelajar bahasa mandarin pemula untuk dapat mengumpulkan data dan menemukan kesalahan pembelajar dalam mempelajari pelafalan bahasa Mandarin. Kemudian akan dilakukan analisa terhadap kesalahan berbahasa tersebut. Kemudian secara empirik akan dilakukan implementasi pembelajaran mobile learning untuk dapat mengukur keefektivitasan pembelajaran pelafalan mandarin dengan bantuan media tersebut. Dari data evaluasi yang didapat akan dilakukan penghitungan evaluasi secara kuantitatif.

\section{Pengertian Bahasa}

Bahasa adalah merupakan alat komunikasi yang digunakan oleh manusia. Beberapa ahli mendefinisikan arti bahasa diantaranya yaitu menurut Kridalaksana (dalam Imam Asrori) (2008) bahasa adalah system lambang bunyi yang atbitrer, yang dipergunakan oleh para anggota suatu masyarakat untuk bekerja sama, berinteraksi, dan mengidentifikasikan diri.

Menurut Kamus Besar Bahasa Indonesia (2007). Bahasa, 1. sistem lambang bunyi yang arbitrer, yang dipergunakan oleh para anggota suatu 
masyarakat untuk bekerja sama, berinteraksi, dan mengidentifikasikan diri; 2 . Percakapan (Perkataan) yang baik; tingkah laku yang baik; sopan santun.

Menurut Owen dalam Stiawan (2006:1), menjelaskan definisi bahasa yaitu language can be defined as a socially shared combinations of those symbols and rule governed combinations of those symbols (bahasa dapat didefenisikan sebagai kode yang diterima secara sosial atau sistem konvensional untuk menyampaikan konsep melalui kegunaan simbol-simbol yang dikehendaki dan kombinasi simbolsimbol yang diatur oleh ketentuan)

Pengertian Bahasa menurut Harum Rasyid, Mansyur dan Suratno (2009:26), Bahasa merupakan struktur dan makna yang bebas dari penggunaanya,sebagai tanda yang menyimpulkan suatu tujuan.

Wibowo, Walija (2009:12) berpendapat bahwa "bahasa ialah komunikasi yang paling lengkap dan efektif untuk menyampaikan ide, pesan, maksud, perasaan dan pendapat kepada orang lain".

Pengertian Bahasa menurut Keraf smarapradhipa (2005) Bahasa merupakan alat komunikasi antara anggota masyarakat berupa simbol bunyi yang dihasilkan oleh alat ucap manusia. Bahasa juga merupakan sistem komunikasi yang mempergunakan simbol-simbol vokal (bunyi ajaran) yang bersifat arbitrer.

Bahasa seringkali dikaitkan dengan budaya manusia, karena bahasa merupakan salah satu budaya yang dibentuk oleh manusia. Sehingga manusia dapat menguasai suatu bahasa secara alamiah.

Bahasa dibagi menjadi Bahasa pertama dan Bahasa kedua. Pengertian bahasa pertama menurut Zhou Xiao Pin (2009) Bahasa Pertama merupakan Bahasa paling awal didapatkan oleh seorang anak, juga merupakan Bahasa yang didapatkan dari orang tua atau lingkungan sekitarnya yang didapatkan secara alami. 
Menurut Liu Xun (2008) Bahasa pertama adalah Merupakan Bahasa yang diperoleh seseorang setelah dia lahir . sedangkan Pengertian Bahasa kedua menurut Zhou Xiao Pin (2009) adalah Merupakan Bahasa lain yang dipelajari setelah Bahasa pertama. Pengertian Bahasa kedua menurut Liu Xun (2008) adalah Merupakan Bahasa lain yang digunakan dan dipelajari setelah mendapatkan bahasa pertama.

Tim Pengembang Ilmu Pendidikan FPI-UPI (2007) menyatakan sangatlah penting bagi guru untuk mengetahui apakah mengajarkan bahasa Mandarin ini sebagai B2 (bahasa kedua) atau BA (bahasa asing), karena faktor ini sangat menentukan sistem dan metode pengajaran yang akan dipilih selanjutnya.

Dari pengertian Bahasa pertama dan Bahasa Kedua dirasakan penguasaan kemampuan bahasa kedua tidak akan pernah sebaik penguasaan bahasa pertama. Sehingga Pembelajar yang sedang mempelajari bahasa Mandarin sebagai bahasa Kedua memerlukan kerja keras untuk dapat menguasai bahasa tersebut dengan baik.

\section{Definisi Bahasa Mandarin}

Bahasa Mandarin merupakan bahasa Nasional yang diakui oleh Pemerintah RRT yang digunakan di Tiongkok, Bahasa Mandarin didasarkan pada pelafalan Daerah Utara Tiongkok (Beijing). Menurut Zhu Dexi Bahasa Mandarin atau Hanyu adalah salah satu bahasa utama di dunia dan merupakan Rumpun bahasa Sino-Tibet, di dalam Strata Bahasa Sino-Tibet bahasa Mandarin merupakan yang paling penting. Bahasa Mandarin digunakan di China Daratan dan Taiwan, Bahasa Mandarin juga banyak digunakan di Singapura, Malaysia dan tempat-tempat lainnya. Bahasa Mandarin digunakan kurang lebih 1,3 miliar sebagai penutur bahasa pertama atau bahasa Ibu. Bahasa Mandarin juga merupakan bahasa resmi yang diakui oleh PBB. Bahasa Mandarin hampir berabad-abad telah berkembang yang didasarkan pada standar pelafalan daerah utara (Beijing)is Mandarin. Di RRT Bahasa Mandarin disebut sebagai Putonghua, 
di Taiwan disebut dengan Guo Yu, sedangkan di Singapura dan Malaysia disebut dengan Hua Yu.

Bahasa Mandarin memiliki peranan yang sangat penting dalam kehidupan di segala bidang. Di Indonesia, penguasaan bahasa Mandarin cukup tertinggal dengan negara-negara tetangga dikarenakan oleh sejarah larangan bahasa dan budaya Tionghoa di Indonesia dari Tahun 60an, tetapi pada saat ini Bahasa Mandarin sangat dibutuhkan oleh dunia bisnis dan dunia industri. Makin banyak perusahaan dari Tiongkok yang menanmkan modal dan membuka perusahaan di Indonesia. Bahasa Mandarin sudah menjadi salah satu bahasa yang mendunia.

\section{Tentang Pelafalan Hanyu Pinyin Bahasa Mandarin}

Di Dalam Pelafalan Bahasa Mandarin memiliki beberapa perbedaan dengan pelafalan Bahasa Indonesia di dalam konsonan, vocal dan nada sehingga dalam hal ini Pembelajar perlu memperhatikan proses pelafalan Bahasa Mandarin. Pengertian pelafalan Hanyu Pinyin menurut Liem A Wijaya \& Leoni A. Wijaya, Alfabet Latin Bahasa Mandarin (Pinyin) merupakan jembatan untuk mengucapkan huruf Han (huruf Mandarin).

\section{Konsonan Bahasa Mandarin}

Menurut Liem A Wijaya \& Leoni A. Wijaya tentang Hanyu Pinyin adalah, konsonan Bahasa Mandarin memiliki ciri-ciri:

1. Pada dasarnya konsonan tidak dapat berdiri sendiri

2. Ada beberapa vocal tunggal yang bisa berdiri sendiri

3. Vocal dalam bahasa mandarin harus diungkapkan dengan lengkap dan jelas

4. Titik dua yang berada di atas " $u$ " harus dihilangkan apabila lafal berawalan konsonan “j”, "q", “x”.

5. Titik dua yang berada di atas " $u$ " harus tetap diadakan, apabila lafal berawalan konsonan "l"

Konsonan Bahasa Mandarin antara lain: 
b, p, m, f, d, t, n, l, g, k, h, r, j, q, x, zh, ch, sh, z, c, s

Konsonan Pengganti ada 2 huruf, antara lain: y,w

Vokal Tunggal Bahasa Mandarin memiliki 6 huruf yaitu a, o, e, i, u, ü

Vokal Tunggal lain (4 huruf) r, er, i, -i

Vokal Rangkap (29 Huruf): ai, ei, ao, ou, ia, ie, iao, iou, ua, uo, uai, ui, ue, an, en, ang, eng, ung, ian, in, iang, ing, iong, uan, uen, uang, ueng, uan, un

Nada

Ciri Khas Bahasa Mandarin yang tidak dimiliki oleh Bahasa Indonesia adalah penggunaan Nada dalam pengucapannya. Di dalam Bahasa Mandarin perbedaan nada akan memberikan perbedaan arti, menurut Zhou Xiao Bing Nada dalam Bahasa Mandarin terdiri atas empat nada dan di beberapa keadaan kosakata bisa dibaca nada netral

Berikut adalah posisi cara baca nada dalam bahasa mandarin sesuai tangga nada:

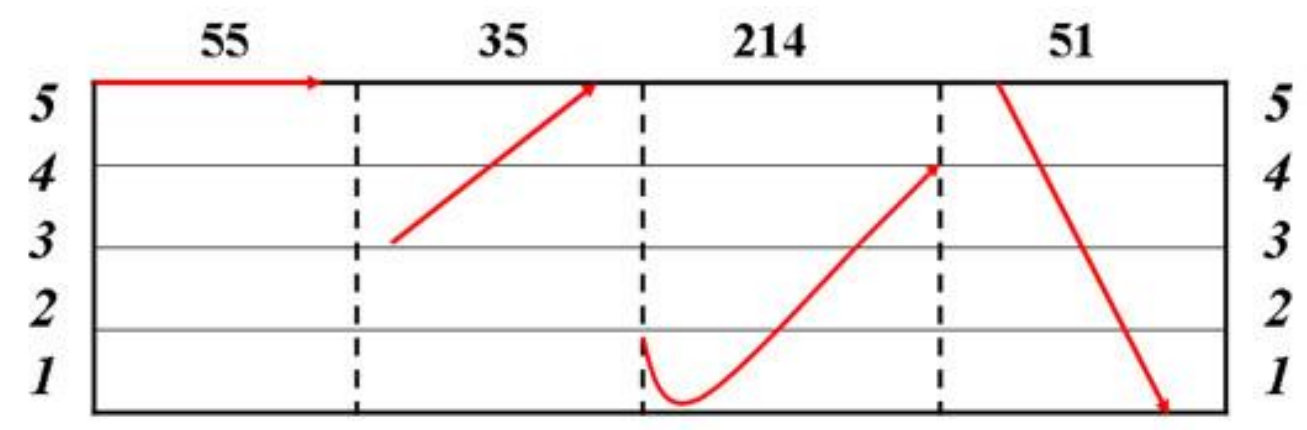

Gambar 2. Gambar Nada Dalam Bahasa Mandarin

\section{Tentang Media Aplikasi Handphone}

Fungsi Media menurut Tejo Nurseto (2012) dapat ditekankan beberapa hal berikut ini yaitu sebagai alat untuk membuat pembelajaran yang lebih efektif, mempercepat proses belajar, meningkatkan kualitas proses belajar-mengajar, mengkongkretkan yang abstrak sehingga dapat mengurangi terjadinya penyakit verbalisme. 
Salah satu contoh aplikasi yang dapat digunakan sebagai media pembelajaran adalah aplikasi Hello Chinesese, merupakan aplikasi pembelajaran yang dikembangkan oleh "Learn Chinese Mandarin" yang bertempat di Zhongguancun street, Haidian, Beijing, China untuk pembelajar Bahasa Mandarin Pemula yang bisa diunduh di Google Play atau App Store. Dasar Permainan ini adalah sesuai kurikulum pembelajar pemula, dan mendorong pembelajar pemula untuk termotivasi.

Sistematika konten meliputi berbagai macam aspek, yaitu Membaca, Menulis, Berbicara/melafalkan, kosakata dan tata bahasa. Dalam pelatihan pelafalan disediakan pembetulan pelafalan yang baik dan benar sesuai dengan pelafalan Hanyu Pinyin.

Penggunaan Aplikasi di Handphone berkembang dengan sangat pesat, tetapi penggunaan aplikasi tersebut untuk digunakan oleh peserta didik masih perlu ditingkatkan, pandangan penggunaan telepon gengam atau Handphone untuk digunakan sebagai media pembelajaran antara lain menurut Dody Iskandar (2010) Peningkatan jumlah pengguna telepon genggam telah membuka peluang untuk dikembangkannya media pembelajaran dengan konsep mobile learning sehingga belajar dapat dilakukan dimana pun dan kapan pun tanpa terikat ruang dan waktu.

Pengertian Mobile Learning menurut Saedah Siraj (2004) Pembelajaran Mobile merupakan pembelajaran yang menyediakan ruang komunikasi yang lebih mudah dan cepat. lni memberi peluang kepada pelajar melibatkan diri secara fisikal dan mental dalam pembelajaran. Oleh karena sifat pembelajarannya lebih memberi pertimbangan kepada upaya dan kesediaan sendiri, Pcmbelajaran Mobile membolehkan pelaksanaan penilaian segera dan dinamik terhadap kemajuan pelajar. Selain itu Aplikasi mobile bahasa Mandarin dapat secara signifikan dapat membantu meningkatkan kompetensi siswa Darmanto dkk. (2016). 
Keefektivitasan pembelajaran

Pembelajaran yang dilakukan harus dilakukan seefektif mungkin agar sesuai dengan tujuan mencapai kompetensi yang diharapkan, keefektivitasan Pembelajaran menurut Prof Suyanto dan drs. Asep (2013) yang mengutip dari McWhorter yang mengatakan bahwa pembelajaran yang efektif juga memerlukan efisiensi, efisiensi adalah kemampuan untuk menunjukkan sesuatu dengan sedikit usaha, biaya, dan pengeluaran untuk mencapai hasil yang maksimal. Efisiensi mencakup penggunaan waktu dan sumber daya secara efektif untuk menyelesaikan tugas tertentu.

Prof Suyanto dan drs. Asep (2013) mengungkapkan bahwa ada dua hal yang diperlukan guna mencapai pembelajaran yang efektif. Pertama, harus ada kegiatan analisis kebutuhan belajar siswa. Kebutuhan siswa adalah bagaimana menganalisis hubungan antara kemampuan dan harapan siswa dari proses pembelajarannya. Kedua, harus ada gambaran seperti apa sistem ujian yang dipakai. Dengan demikian, pembelajaran yang efektif harus mempunyai syarat kesesuaian antara kebutuhan belajar siswa dan sistem ujian. (hal.102).

\section{Hasil}

Penelitian ini dilakukan dengan melakukan perbandingan pengajaran menggunakan media aplikasi mobile learning dan tanpa menggunakan media. Total siswa yang diteliti adalah sebanyak 60 orang, kemudian dilakukan evaluasi terhadap pelafalan konsonan masing-masing pembelajar sebelum dan sesudah menggunakan media Mobile Learning.

Tabel 1. Hasil Perbandingan keefektivitasan penggunaan media mobile learning

\begin{tabular}{|c|c|c|}
\hline \multicolumn{3}{|c|}{$\begin{array}{l}\text { PERBANDINGAN KEEFEKTIVITASAN PENGGUNAAN } \\
\text { MOBILE LEARNING }\end{array}$} \\
\hline Konsonan & Kesalahan yang ditemukan & Selisih \\
\hline
\end{tabular}

318 | http://journal.unesa.ac.id/index.php/paramasastra 
Budi Hermawan dan Ong Peter L, Keefektifan Penggunaan... (hlm. 308-322)

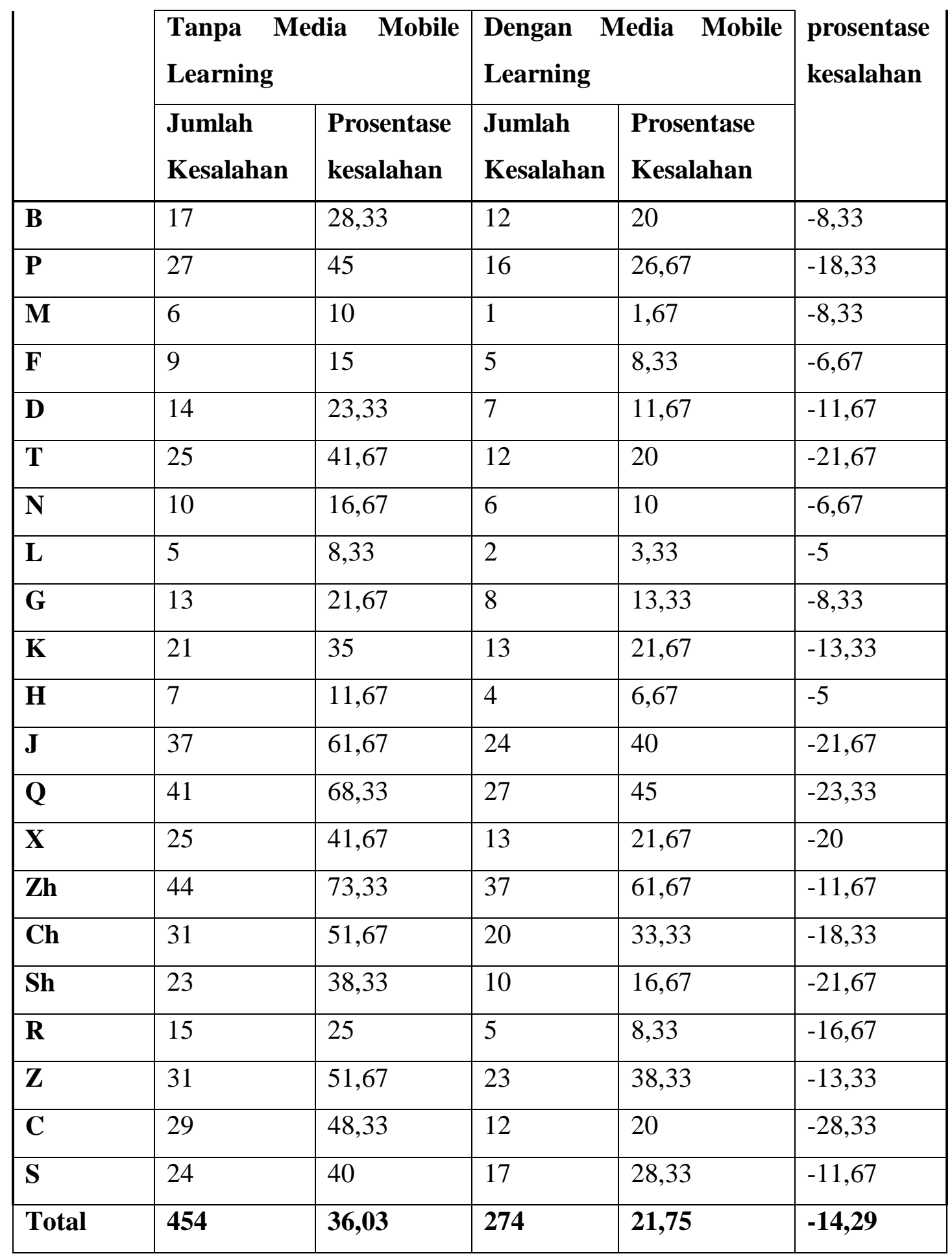




\section{SIMPULAN}

Dari hasil penelitian kuantitatif yang telah dilakukan terhadap pembelajar awal Bahasa mandarin, didapatkan simpulan sebagai berikut:

1. Perbandingan Kesalahan Pembelajar Awal Bahasa Mandarin dalam melafalkan konsonan dasar sebelum menggunakan media pembelajaran mobile learning adalah 454 kesalahan (36,03\%), setelah menggunakan media pembelajaran mobile learning terjadi penurunan 274 kesalahan (21,75\%), sehingga selisih prosentase kesalahan $14,29 \%$.

2. Berdasarkan hasil penelitian perbandingan di atas maka dapat disimpulkan pembelajaran konsonan Bahasa Mandarin dengan menggunakan media pembelajaran mobile learning dapat mengurangi jumlah kesalahan pelafalan peserta didik.

3. Jumlah kesalahan pelafalan terbesar yaitu pada konsonan "zh" ditemukan sebanyak 44 kesalahan yang dilakukan $(73,33 \%)$, kemudian setelah peserta didik menggunakan media pembelajaran, terjadi penurunan menjadi 37 kesalahan $(61,67 \%)$.

4. Jumlah kesalahan pelafalan terkecil yaitu pada konsonan "l" hanya ditemukan sebanyak 5 kesalahan $(8,33 \%)$, kemudian setelah peserta didik menggunakan media pembelajaran mobile learning terjadi penurunan menjadi 2 kesalahan $(3,33 \%)$

\section{Saran}

Untuk perkembangan lebih lanjut, maka hal yang disarankan antara lain untuk pengembangan pembelajaran Bahasa Mandarin bagi Pemula yaitu: 
Budi Hermawan dan Ong Peter L, Keefektifan Penggunaan... (hlm. 308-322)

1. Dalam Mempelajari pelafalan Bahasa Mandarin terutama konsonan, peserta didik membutuhkan media pembelajaran mobile learning untuk bisa meningkatkan kompetensi pelafalan peserta didik.

2. Dalam Proses pembelajaran Bahasa Mandarin, terutama pengajaran pelafalan, Pengajar dapat memanfaatkan teknologi yaitu Media pembelajaran aplikasi yang dapat meningkatkan keefektivitasan pembelajaran pelafalan Hanyu Pinyin.

3. Penelitian ini dapat ditindaklanjuti dengan pengukuran keefektivitasan pembelajaran vokal bahasa mandarin, maupun pembelajaran kosakata dan tata bahasa.

\section{DAFTAR PUSTAKA}

Alwi, Hassan. (2007). Kamus Besar Bahasa Indonesia. Jakarta: Balai Pustaka. Andriyani, F. (2015). Teori Belajar Behavioristik dan Pandangan Islam tentang Behavioristik. Syaikhuna, 1(1), 165-180.

Asrori, Imam.(2008), Sintaksis Bahasa Arab. Malang: Misykat

Darmanto, Yulius Hari, dan Budi Hermawan., (2016). Mobile Learning Application to Support Mandarin Language Learning for High School student. Imperial Journal of Interdiciplinary Research., Vo. 2, No. 4,. ISSN: 2454-1362, Diakses dari : http://www.onlinejournal.in, 3 Maret 2016.

Iskandar, D., \& Soesianto, I. F. (2010). Pengembangan aplikasi berbasis teknologi mobile untuk pembelajaran (Doctoral dissertation, Universitas Gadjah Mada).

Keraf, Gorf (2005). Komposisi Sebuah Pengantar Kemahiran Bahasa (edisi ketujuh). Ende: Nusa Indah. 
Liem, Wijaya A. \& Liem, Leoni Wijaya (2010). Mudah Melakukan Percakapan Bahasa Mandarin Sehari-hari. Jakarta: Tangga Pustaka

Liu Xun (2008) dui wai hanyu jiaoyuxue yinlun. Beijing: Beijing yuyan daxue press

Moleong, Lexy(1995). Metode penelitian. Bandung: Remaja Rosda Karya.

Nurseto, T. (2012). Membuat media pembelajaran yang menarik. Jurnal Ekonomi \& Pendidikan, 8(1).

Prof. Suyanto\& Drs. Jihad, Asep. (2013). Menjadi Guru Profesional. Jakarta: Erlangga.

Siraj, S., \& Saleh, M. (2004). Pembelajaran Mobile dalam kurikulum masa depan. Masalah pendidikan, 27, 128-142.

Tim Pengembang Ilmu Pendidikan FPI-UPI. (Cet. III). (2007). Ilmu dan aplikasi pendidikan. Bandung : Grasindo Intima.

Zhou Xiao Bing (2012) The Guidance Of Teaching Chinese To Speakers Of Other Languages. Guangzhou: Zhongshan Daxue Press. 